\title{
Redescription of Astyanax erythropterus (Holmberg, 1891) (Teleostei: Characiformes: Characidae) from La Plata basin in Argentina
}

\author{
Paula Soneira ${ }^{1}$, Jorge Casciotta ${ }^{2,3}$, Adriana Almirón², Liliana Ciotek ${ }^{4}$ and Pablo Giorgis ${ }^{4}$
}

\begin{abstract}
Astyanax erythropterus (Holmberg, 1891) originally described on the basis of one juvenile, is redescribed herein based on juveniles and adults from the type-localiy. The species differs from its congeners by the combination of 11-13 transverse rows scales above lateral line and 8-10 rows below lateral line; 49-54 perforated scales in the lateral series; iii-v,38-42 anal-fin rays, and dorsal, anal and caudal fins vermilion red in juveniles. The vermilion red coloration of unpaired fins in juveniles of Astyanax is only known in A. correntinus.
\end{abstract}

Astyanax erythropterus (Holmberg, 1891) originalmente descripta sobre la base de un ejemplar juvenil, es redescripta en base a ejemplares juveniles y adultos de la localidad tipo. La especie se diferencia de sus congéneres por la combinación de 11-13 hileras de escamas transversas por encima de la línea lateral y 8-10 hileras debajo de la línea lateral; 49-54 escamas perforadas en las serie lateral; iii-v,38-42 radios en la aleta anal y juveniles con las aletas dorsal, anal y caudal rojo bermellón. Aletas impares rojo bermellón en ejemplares juveniles de Astyanax son solo conocidas en A. correntinus.

Key words: Neotropical region, Color pattern, Juveniles.

\section{Introduction}

When Holmberg described nine species of fishes from Argentina in 1891, he deposited most of the material in the Museo de la Escuela Normal de Profesoras de la Capital (Buenos Aires City). Several ichthyologists, including one of us (JC), have searched the Biology laboratory of the above mentioned institution looking for Holmberg's specimens without success; therefore, unfortunately, this material seems to be lost. As it was the rule at the time of Holmberg's publication, the descriptions of these species were rather short; thus, some species were redescribed many years after the original publication. This is the case of Crenicichla niederleinii (Kullander, 1981) and Astyanax correntinus (Mirande et al., 2006).

During several collecting trips in the río Paraná as part of intensive studies in the Pre-Delta National Park, allowed us to find juveniles of Astyanax species with unpaired fins vermilion red, a character considered distinctive by Holmberg (1891) for A. erythropterus.
The aim of this paper is to provide a redescription for Astyanax erythropterus originally described from the río de la Plata and Paraná [río Paraná] in Argentina based on juveniles and adults specimens.

\section{Material and Methods}

Measurements were taken point to point using digital callipers. Counts were taken following Fink \& Weitzman (1974) and Bertaco \& Lucena (2006). Counts of vertebrae and gill-rakers were taken from cleared and stained (c\&s) specimens preapared according Taylor \& van Dyke (1985) methods. Vertebral counts included the four vertebrae of the Weberian apparatus and the terminal centrum counted as a single element. Frequency of the counts are shown between parentheses. Institutional abbreviations are as listed in Ferraris (2007), with the exception of Asociación Ictiológica, La Plata (AI).

\footnotetext{
${ }^{1}$ Instituto de Ictiología del Nordeste, Facultad de Ciencias Veterinarias, UNNE. Sargento Cabral 2139, 4300 Corrientes, Argentina. paulaasoneira@hotmail.com

${ }^{2}$ Museo de La Plata, UNLP. Paseo del Bosque s/n, 1900 La Plata, Argentina.jrcas@fcnym.unlp.edu.ar, aalmiron@fcnym.unlp.edu.ar

${ }^{3}$ Comisión de Investigaciones Científicas de la Provincia de Buenos Aires (CIC), Argentina.

${ }^{4}$ Administración de Parques Nacionales, Argentina. lilianaciotek@hotmail.com
} 


\section{Astyanax erythropterus (Holmberg, 1891)} Figs. 1-4

Diagnosis. Astyanax erythropterus is distinguished from all species of the genus, except $A$. pelegrini, by the presence of a long anal fin bearing 38 to 42 branched rays ( $v s$. 34), a large number of perforated scales on the lateral series (49-54 vs. 48), and the juveniles (18.0-29.9 mm SL; Fig. 1) with the dorsal, anal and caudal fins vermilion red. Astyanax erythropterus differs from $A$. pelegrini by the number of transverse scales below the lateral line (8-10 vs. 7-8). Astyanax erythropterus can be distinguished from the six sympatric species by the great number of branched anal-fin rays 38-42 ( $v s$. 30-34 in $A$. abramis, 30-32 in A. asuncionensis, 29-33 in A. correntinus; 22-24 in A. eigenmanniorum; 23-26 in A. rutilus; and 25-30 in A. stenohalinus).

Description. Body deep, with maximum body depth located at dorsal-fin origin (Figs. 1-4). Dorsal profile of head slightly convex from snout tip to vertical through anterior margin of eyes, concave from this last point to supraoccipital spine in adults, slightly convex in juveniles. Dorsal profile of body markedly convex from tip of supraoccipital spine to base of first dorsal-fin ray in adults, slightly convex in juveniles. Dorsal profile slanting ventrally from dorsal-fin origin to caudal peduncle; slightly concave on caudal peduncle. Ventral profile of body convex from tip of lower jaw to anal-fin origin, posterodorsally slanted along analfin base, slightly concave on caudal peduncle. Dorsal-fin origin almost equidistant from snout tip and caudal-fin base. Pelvic-fin origin anterior to vertical through dorsal fin-origin. Anal-fin origin slightly posterior to vertical through base of last dorsal-fin ray. Origin of adipose fin at vertical through base of 25-27 branched anal-fin rays. Tip of longest pectoral-fin rays always extending slightly beyond pelvic-fin origin. Tip of longest pelvic-fin rays not reaching anal-fin origin in adult specimens, reaching or extending slightly beyond this point in specimens less than $60 \mathrm{~mm}$ SL. Head short, mouth terminal; snout relatively short and blunt. Lower and upper jaws isognathous. Premaxilla ascending process triangular-shaped; alveolar process long, bearing two series of teeth. Outer row with 4 or 5 tricuspid or pentacuspid teeth, not expanded distally, with central cusp larger, and lateral ones well-developed. Third tooth slightly displaced in relation to remaining outer row teeth. Inner row teeth 5, each with 4 to 7 cusps (Fig. 5a). Anterodorsal process of maxilla long, lateral process laminar, long and slender. Maxilla with one tooth with 5 or 7 cusps (Fig. 5a). Dentary with four anterior large teeth with 5 or 7 cusps, followed by one medium size tooth with 4 to 5 cusps, and four smaller ones with 1 to 3 cusps (Fig. $5 b$ ). Eye larger than snout, interorbital distance wide. Third infraorbital not contacting latero-sensory canal of preopercle either ventrally or posteriorly. Dorsal fin ii-iii, 8 (2), 9(25); when 3 unbranched rays present, first very short; last unbranched dorsal-fin ray longest. Anal fin iii-iv,38 (3), 39 (8), 40(11), 41(6), 42(2), 43(1), 45(1) rays. Principal caudal fin-rays i,17,i. Lower caudal-fin lobe slightly longer than upper one. Pectoral-fin rays i,12 (2), 13 (21), 14 (5); distal margin of fin slightly curved. Pelvic-fin rays i,7; pelvic-fin distal margin slightly curved. Scales cycloid. Lateral line series with 47 (1), 49 (10), 50 (7), 51(6), 52(3),

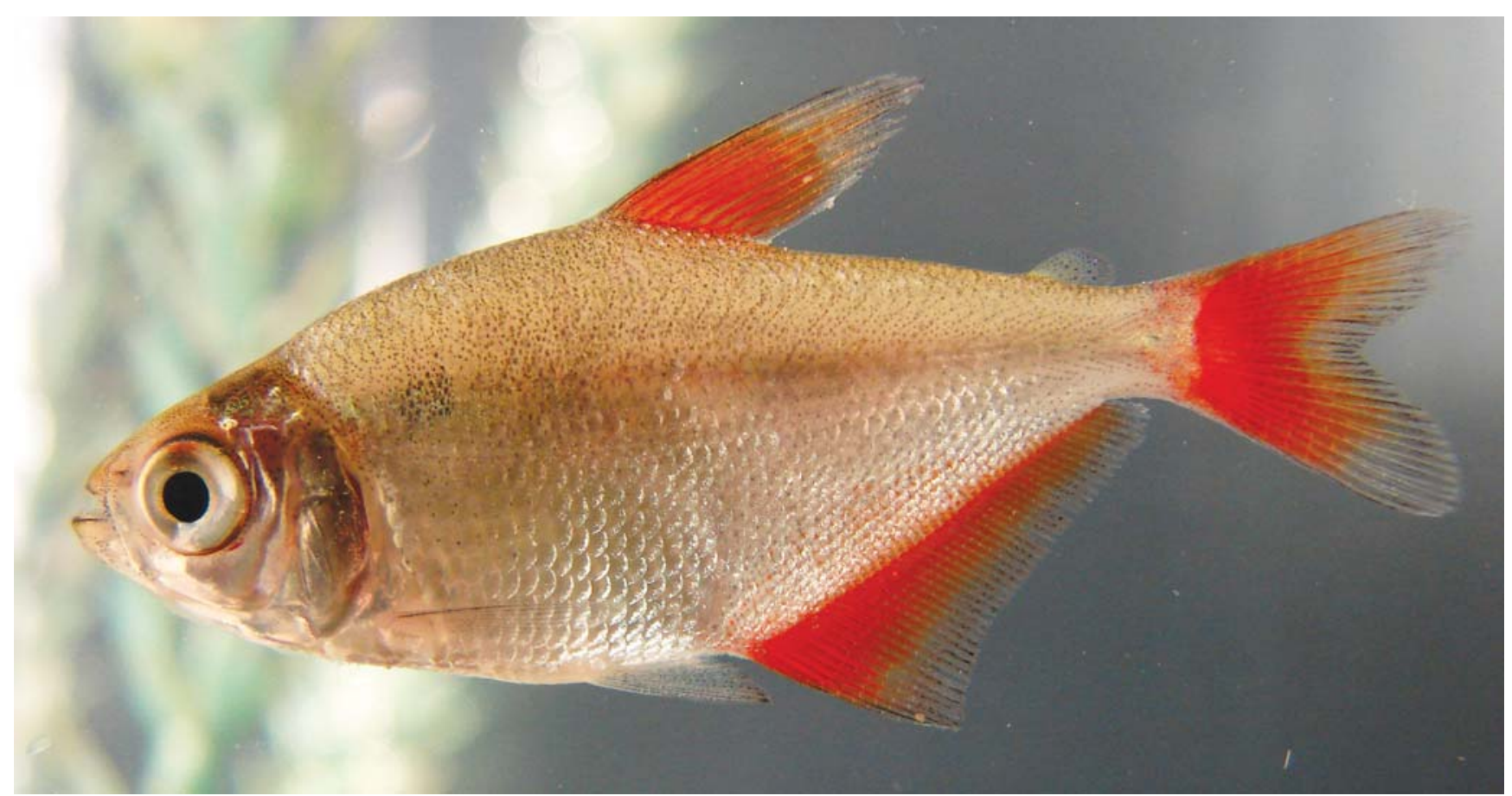

Fig. 1. Astyanax erythropterus (juvenile), MACN-ict 9453, 29.9 mm SL, Argentina, Provincia de Entre Ríos, Parque Nacional Pre-Delta, río Paraná basin. Photographed in life. 
53(2), 54(1) perforated scales. Eleven to thirteen longitudinal scale rows between dorsal-fin origin and lateral line; 8 to 10 between lateral line and pelvic-fin origin. Scales around caudal peduncle 18-20. Thirty-five to thirtynine scales along anal-fin base, covering bases of all unbranched and branched anal-fin rays. Twenty percent of caudal fin base covered by scales. First branchial arch with 24 gill-rakers (15 on ceratobranchial, 1 on cartilage, and 8 on epibranchial) (2). Total vertebrae: 33 (2).

Morphometrics characters of 28 specimens are presented in Tables 1-2 and Fig. 6. Absolute and log-transformed data were used to test differences in means of morphometric attributes between juveniles and adults. Test results shown that mean value of each attibutes were significantly different between both groups ( $t$-Test; $\mathrm{p} \leq 0.05$; Table 1$)$. Lineal equation provided a very good fit to the relationships between both standard and head length and morphometric attributes $\left(\mathrm{R}^{2}=0.84\right.$ $0.99 ; p \leq 0.05$; Table 2). Most of regressions shown higher slopes in juveniles than in adults, specially in pectoral and pelvic-fin length and predorsal length (Fig. 6). The differences of the slopes betwen groups were not-significant in all cases $(t$-Test; $\mathrm{p} \leq 0.05)$. Therefore, we conclude that morphometrics changes during the ontogeny would be not very deep.
Color in alcohol. Background light yellow, dorsal region of body and head darker (Figs. 3-4). Dark narrow stripe extending along dorsal midline from supraoccipital spine tip to base of dorsalmost caudal-fin ray. Dark lateral band wide beginning at upper opercular posterior margin, ending with a triangular spot on caudal peduncle. Adults usually with faint dark vertically elongated humeral spot situated between $4^{\text {th }}$ to $7^{\text {th }}$ scales of longitudinal series above lateral line, upper half of humeral spot wider than lower half. Humeral spot always present in juveniles, absent in some adults. Scales of upper half of body with scattered dark chromatophores. Small chromatophores present on premaxilla and lower jaw regions. Gray chromatophores aligned on dorsal margin of lower jaw region. Dorsal and adipose fins pale gray; dorsal fin with scattered black chromatophores on its surface, adipose fin with black cromatophores more concentrated on its margin. Caudal fin pale gray with small black chromatophores on distal margin. Anal fin pale yellow. Pectoral fin pale gray with scattered chromatophores on first five rays. Pelvic fins pale yellow.

Color in life. Adults (Fig. 2): background silvery, dorsal region of body and head with green glints. Wide silvery lateral band from posterior opercular margin and ending as a triangular

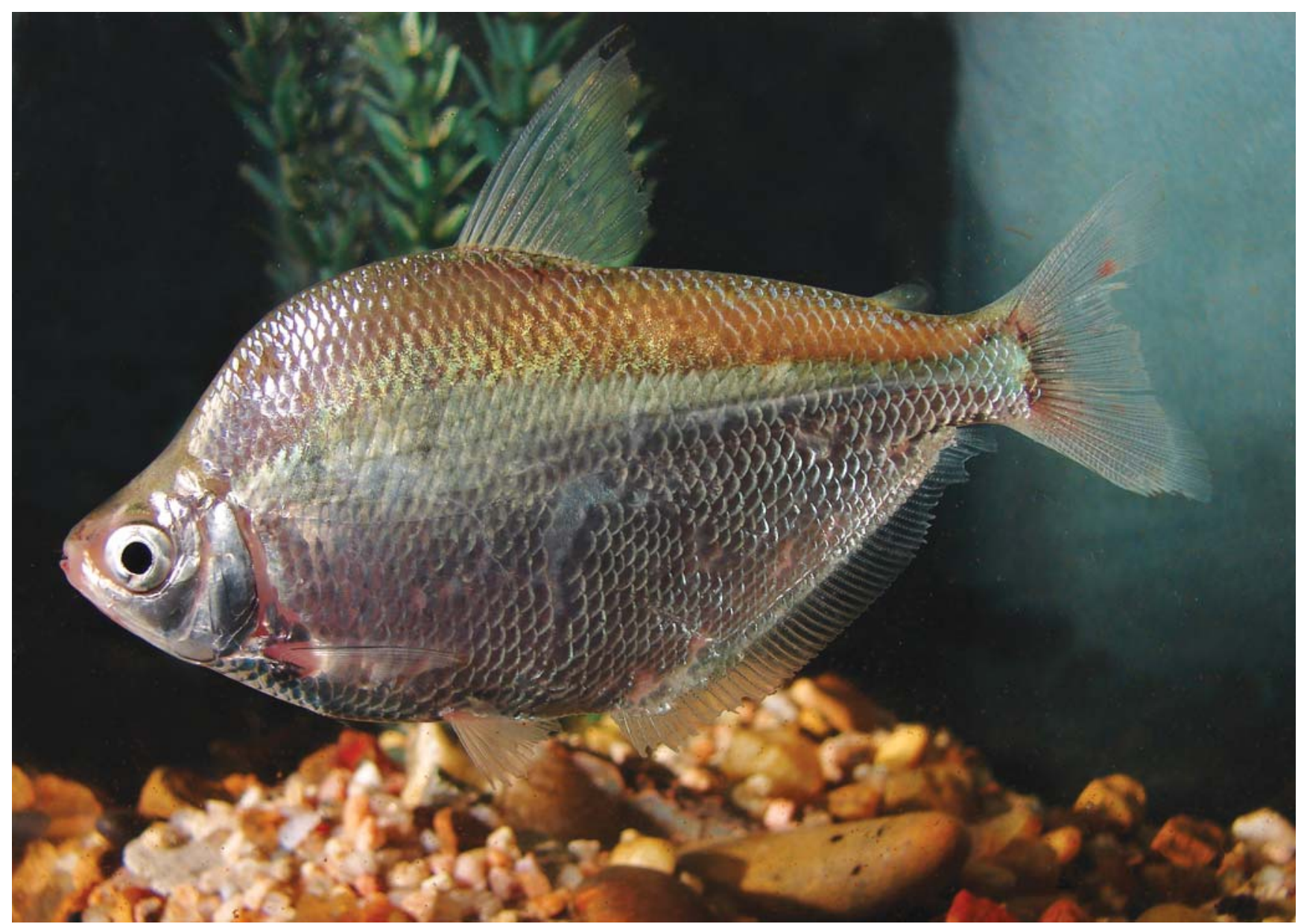

Fig. 2. Astyanax erythropterus (adult), MACN-ict 9455, 89.3 mm SL, Argentina, Provincia de Entre Ríos, Parque Nacional PreDelta, río Paraná basin Rowing Club, mouth of the Arroyo La Ensenada. Photographed in life. 


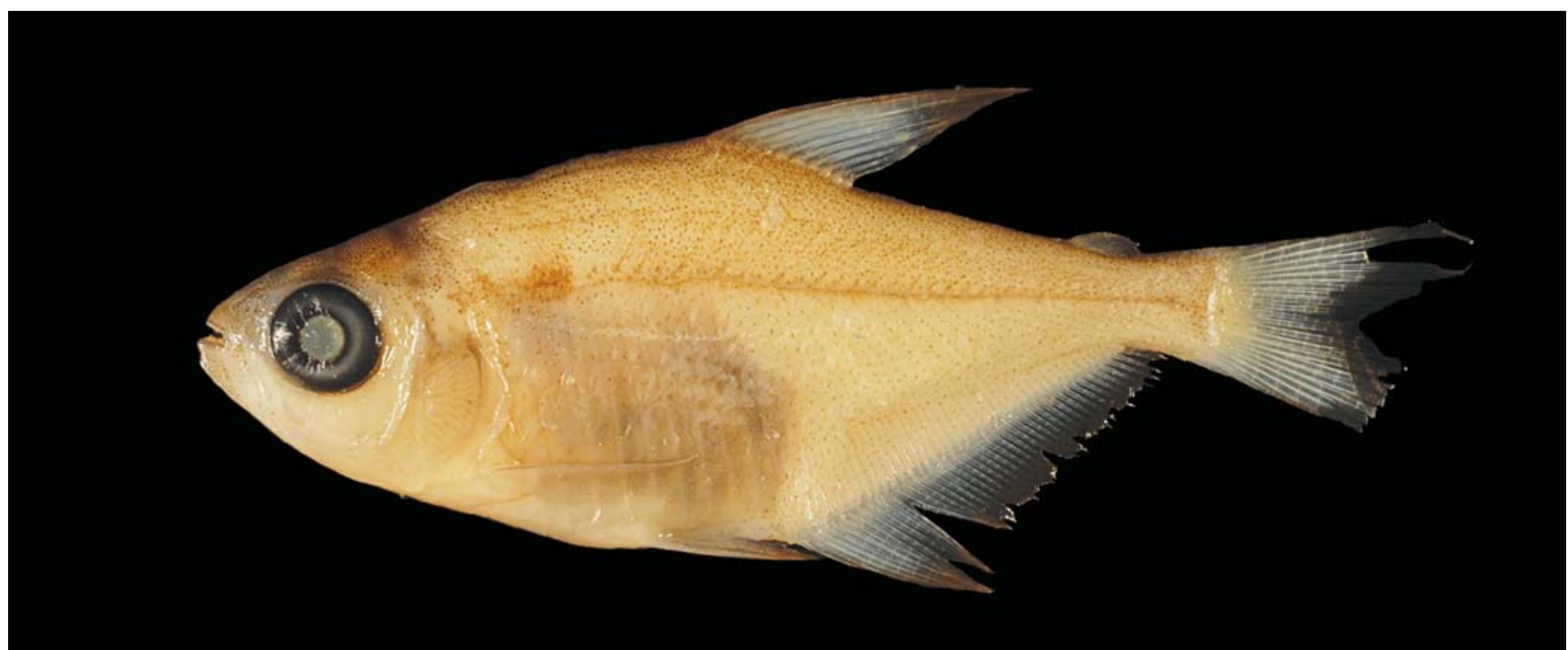

Fig. 3. Astyanax erythropterus (juvenile), MACN-ict 9453, 29.9 mm SL, Argentina, Provincia de Entre Ríos, Parque Nacional Pre-Delta, río Paraná basin.

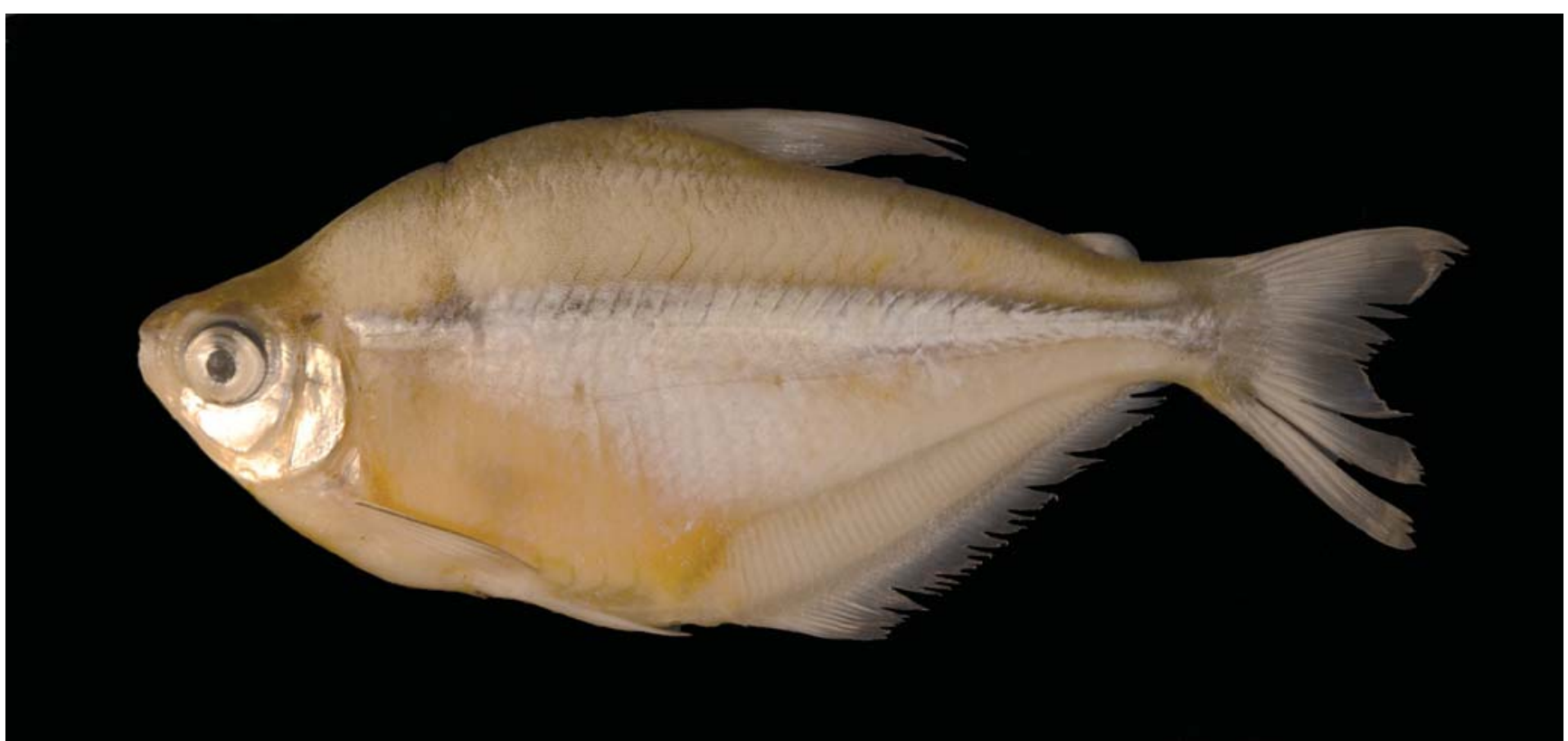

Fig. 4. Astyanax erythropterus (adult), MACN-ict 9448, 88.4 mm SL, Argentina, Provincia de Corrientes, ciudad de Yahapé, río Paraná.

spot on caudal peduncle. Dark humeral spot on flank very faint, some specimens with a second very faint lateral spot 4 or 5 scales behind the humeral spot. Dorsal and adipose fins hyaline; dorsal fin with scattered black chromatophores. Caudal fin hyaline with dark area on base and scattered chromatophores on rays. Anal and pectoral fins hyaline. Pectoral fins with scarce chromatophores on first ray. Pelvic fins hyaline.

Juveniles (Fig. 1): Background of midventral body silvery, dorsal region of body and head darker with black chromatophores. Body areas closer to anal-fin base, caudal and dorsal fin with scattered red chromatophores. Small dark chromatophores on premaxilla and lower jaw regions. Gray chromatophores aligned on dorsal margin of lower jaw region.
Dark humeral spot on flank. Dorsal, anal and caudal fins vermilion red, with distal third hyaline and bearing scattered dark cromathophores. Adipose, pectoral and pelvic fins hyaline with scattered dark chromatophores.

Sexual dimorphism. Secondary sexual dimorphism was found on anal and pelvic-fin rays of males and body depth. Males have hooks on last unbranched and following 22 to 30 branched anal-fin rays. Anal-fin hooks on posterior branches of rays, one pair on each segment curved dorsally. Pelvic fin of males with 8 to 18 small hooks on first to sixth branched rays, one or two on each segment. Body of males less deep than in females (42.8-47.5 vs. 46.0-48.6\% of SL, respectively). 


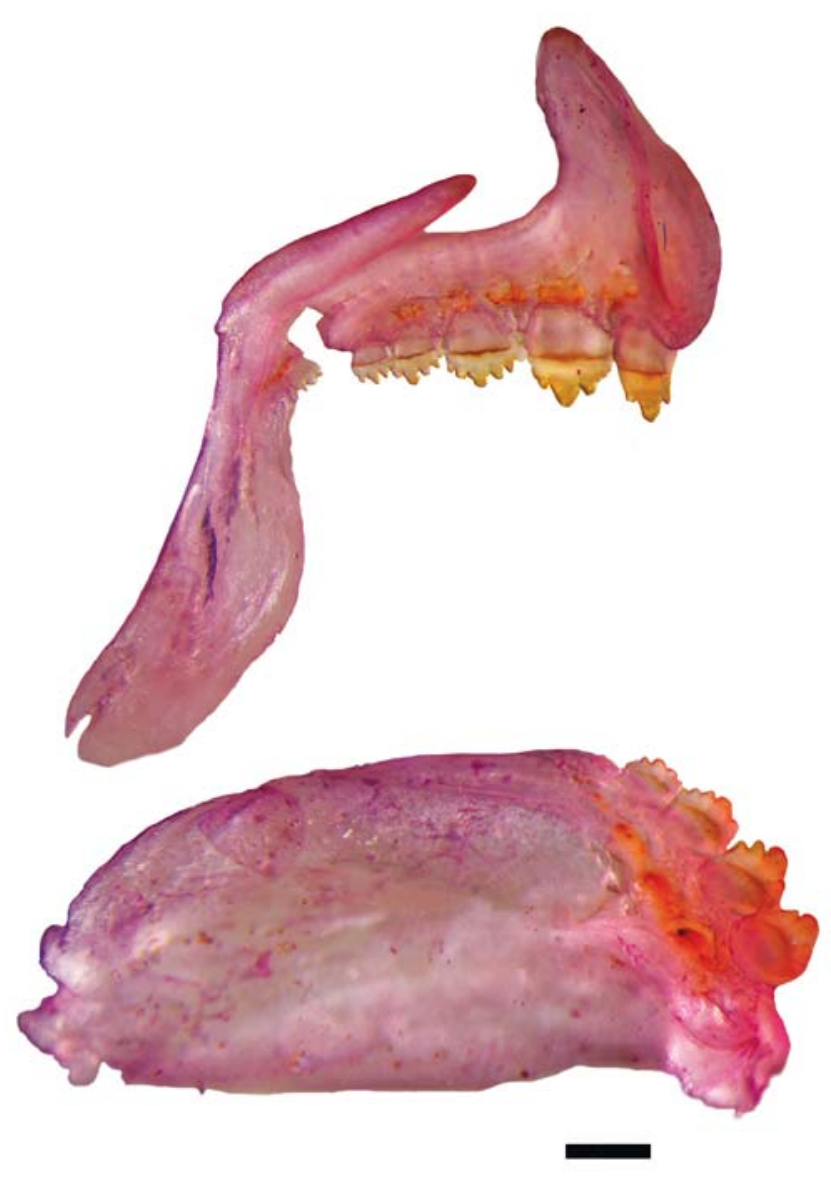

Fig. 5. Astyanax erythropterus, AI 265, $84.7 \mathrm{~mm}$ SL: left premaxilla, maxilla, and lower jaw, internal view. Scale bar $=1 \mathrm{~mm}$.

Distribution. Astyanax erythopterus was found in the middle and lower río Paraná and Río de la Plata basin (Fig. 7).

Material examined. Astyanax erythropterus: Argentina: Provincia de Chaco: MACN-ict 8568, 4, 36.9-56.5 mm SL, Chaco without other data. Provincia de Corrientes: MACN-ict 9448, 14, 78.4-96.9 mm SL, ciudad de Yahapé, río Paraná. AI 265, 1 c\&s, 84.7 mm SL, ciudad de Yahapé, río Paraná. MACN-ict 9449, 2, 79.2-88.4 mm SL, ciudad de Ituzaingó, río Paraná. Provincia de Buenos Aires, Punta Lara, Río de la Plata basin: MACN-ict 9450, 2, 49.3-55.5 mm SL, Arroyo Capitán. AI 266, 1 c\&s, 48.3 mm SL, Arroyo Capitán. MACN-ict 9451, 3, 36.8$40.9 \mathrm{~mm}$ SL, Arroyo Baldovinos. Provincia de Entre Ríos, Parque Nacional Pre-Delta, río Paraná basin: MACN-ict 9452, 1, $25.7 \mathrm{~mm} \mathrm{SL}$, Arroyo La Ensenada, Camping Municipal. MACN-ict 9453, 1, 29.9 $\mathrm{mm}$ SL, cuneta en camino de acceso. MACN-ict 9454, 1, 18.0 mm SL, Arroyo La Ensenada, Camping Municipal. MACN-ict 9455, 1, 89.3 mm SL, Rowing Club, desembocadura del Arroyo La Ensenada.

\section{Discussion}

Astyanax erythropterus was described by Holmberg in 1891 from the Río de la Plata and Paraná [río Paraná] in Argentina. The species was not mentioned for many years, until Eigenmann (1910) referred to it again for the first time after the original description. Later on, it was cited in several
Table 1. Morphometric data of 28 specimens of Astyanax erythropterus. Adults: $\mathrm{n}=18$ (5 males, 13 females), juveniles: $\mathrm{n}$ $=10$. Morphometric differences between juveniles and adults were statistically significant for all attributes $(t$-Test; $\mathrm{p} \leq 0.05)$. $\mathrm{SD}=$ Standard deviation

\begin{tabular}{lcccccc}
\hline & \multicolumn{3}{c}{ Adults } & \multicolumn{3}{c}{ Juveniles } \\
\cline { 2 - 7 } & Range & Mean & SD & Range & Mean & SD \\
\hline Standard length (mm) & $75.8-96.9$ & 83.8 & - & $36.8-55.5$ & 46.2 & - \\
& Percents of standard length & & & \\
Predorsal length & $50.0-52.7$ & 51.2 & 0.81 & $49.9-56.7$ & 53.1 & 1.94 \\
Prepelvic length & $42.3-45.4$ & 43.8 & 0.89 & $44.6-49.2$ & 46.4 & 1.42 \\
Preanal length & $60.2-64.3$ & 62.4 & 1.10 & $55.2-63.6$ & 61.1 & 2.25 \\
Body depth & $42.8-48.6$ & 46.6 & 1.46 & $42.2-49.6$ & 44.8 & 2.54 \\
Dorsal-fin base & $13.4-15.5$ & 14.4 & 0.63 & $14.0-16.5$ & 15.1 & 0.83 \\
Anal-fin base & $38.3-42.8$ & 40.8 & 1.38 & $37.3-43.8$ & 41.7 & 1.80 \\
Pectoral-fin length & $19.9-23.0$ & 21.1 & 0.88 & $22.1-25.5$ & 23.6 & 1.03 \\
Pelvic-fin length & $16.0-19.3$ & 17.4 & 0.86 & $17.3-19.4$ & 18.4 & 0.68 \\
Length between pectoral & $18.0-23.1$ & 20.1 & 1.18 & $18.2-21.1$ & 19.2 & 0.82 \\
$\quad$ and pelvic-fin origins & & & & & & \\
Length between pelvic & $18.3-23.4$ & 20.9 & 1.43 & $14.5-20.6$ & 17.3 & 1.66 \\
$\quad$ and anal-fin origins & $23.4-25.4$ & 24.5 & 0.59 & $28.0-31.2$ & 29.5 & 1.03 \\
Head length & $10.9-12.3$ & 11.4 & 0.35 & $10.1-11.3$ & 10.8 & 0.35 \\
Peduncle depth & Percents of head length & & & \\
& $21.1-25.1$ & 23.0 & 1.14 & $21.0-28.4$ & 23.9 & 2.29 \\
Snout length & $32.6-38.6$ & 35.7 & 1.85 & $33.2-39.3$ & 36.6 & 1.81 \\
Eye diameter & $32.9-38.0$ & 35.2 & 1.52 & $30.0-34.4$ & 32.0 & 1.47 \\
Interorbital distance & $40.8-46.6$ & 43.1 & 1.70 & $41.8-48.5$ & 44.9 & 1.77 \\
Postorbital length & $19.5-24.6$ & 21.7 & 1.34 & $20.5-28.7$ & 24.0 & 2.57 \\
Maxillary length & $31.8-37.4$ & 34.9 & 1.89 & $24.1-31.9$ & 27.8 & 2.55 \\
Caudal peduncle length & \multicolumn{7}{c}{} & & & &
\end{tabular}

Table 2. Regression statistics for the relationships between morphometric data for A. erythropterus. Slope differences between juveniles and adults were not-significant for all attributes $(t$-Test; $\mathrm{p} \leq 0.05) . \mathrm{R}^{2}=$ determination coefficient; $\mathrm{SD}=$ standard deviation.

\begin{tabular}{lccccc}
\hline Morphometric data & $\mathrm{R}^{2}$ & Slope & $\mathrm{SD}$ & Intercept & $\mathrm{SD}$ \\
\hline \multicolumn{1}{c}{ Standard length } & & & & & \\
Predorsal length & 0.99 & 0.49 & 0.008 & 1.966 & 0.573 \\
Preventral length & 0.99 & 0.41 & 0.007 & 2.501 & 0.490 \\
Preanal length & 0.99 & 0.63 & 0.010 & -0.874 & 0.753 \\
Body depth & 0.98 & 0.49 & 0.013 & -1.738 & 0.918 \\
Dorsal-fin base & 0.97 & 0.13 & 0.005 & 0.776 & 0.348 \\
Anal-fin base & 0.98 & 0.40 & 0.011 & 0.789 & 0.794 \\
Pectoral-fin length & 0.96 & 0.18 & 0.007 & 2.506 & 0.493 \\
Pelvic-fin length & 0.96 & 0.16 & 0.006 & 1.098 & 0.444 \\
Length between pectoral & & & & & \\
and pelvic-fin origins & 0.96 & 0.21 & 0.008 & -0.785 & 0.584 \\
Length between pelvic & & & & & \\
and anal-fin origins & 0.95 & 0.24 & 0.011 & -3.104 & 0.782 \\
Head length & 0.97 & 0.19 & 0.006 & 4.534 & 0.455 \\
Peduncle depth & 0.99 & 0.12 & 0.003 & -0.440 & 0.192 \\
$\quad$ Head length & & & & & \\
Snout length & 0.91 & 0.22 & 0.013 & 0.308 & 0.237 \\
Eye diameter & 0.93 & 0.33 & 0.018 & 0.591 & 0.330 \\
Interorbital distance & 0.96 & 0.40 & 0.016 & -0.980 & 0.293 \\
Postorbital length & 0.96 & 0.41 & 0.016 & 0.549 & 0.300 \\
Maxillary length & 0.84 & 0.18 & 0.015 & 0.818 & 0.278 \\
Peduncle length & 0.90 & 0.47 & 0.032 & -2.530 & 0.587 \\
\hline
\end{tabular}

papers, none of them mentioning specimens examined (e.g. Pozzi, 1945; Ringuelet et al., 1967; Géry, 1977; Cordiviola de Yuan et al., 1984; Liotta et al., 1995, 1996; Almirón et al., 2002; Azpelicueta et al., 2002; 2003; López et al., 2003; Casciotta et al., 2003; Mirande et al., 2004; Menni, 2004; and Liotta, 2006). 
Holmberg (1891) based the original description on morphometric, meristic and color pattern of one specimen of about $29 \mathrm{~mm}$ SL. When Holmberg (1891) described the color pattern of $A$. erythropterus, he emphasized on the vermilion red coloration of its dorsal, anal and caudal fins “....aletas pares claras impares de un rojo vivísimo, casi bermellón (fresco)”.
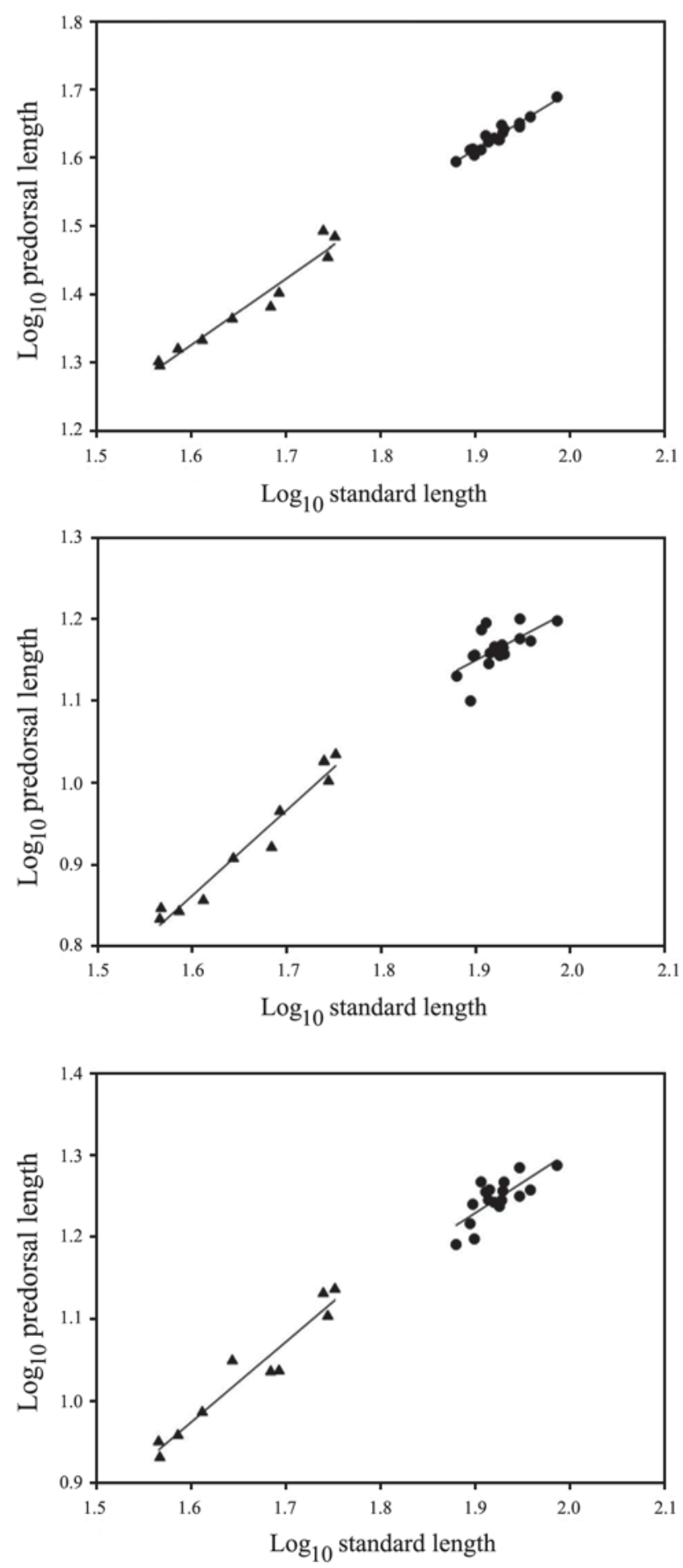

Fig. 6. Scatter plot and regresión line of pelvic-fin length, pectoral-fin length, and predorsal length on standard length in A. erythropterus. Triangles $=$ juveniles; circles $=$ adults.

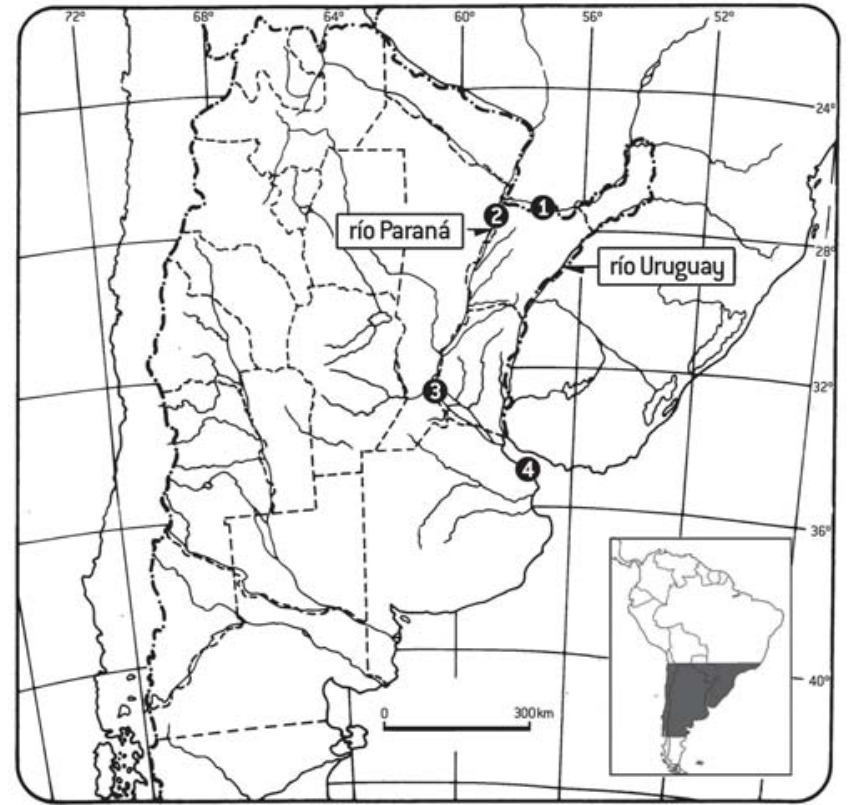

Fig. 7. Distribution of examined material of Astyanax erythropterus. 1) Yahape and Ituzaingó cities. 2) Chaco. 3) Parque Nacional Pre-Delta. 4) Río de la Plata basin.

The color pattern of A.erythropterus varies during ontogeny. In juveniles the dorsal, anal and caudal fins have strong red pigmentation (Fig. 1) whereas the unpaired fins of adults are hyaline (Fig. 2). A similar dichromatic pattern has also been observed in $A$. correntinus, which however, has entirely different meristic counts: 8 longitudinal scale rows between dorsal-fin origin and lateral line; 6 to 7 between lateral line and pelvic-fin origin, iv-v,29-33 anal-fin rays, and 39-42 perforated scales on the lateral line vs. 11 to 13 longitudinal scale rows between dorsal-fin origin and lateral line, 8 to 10 between lateral line and pelvic fin origin, iii-v,3842 anal-fin rays, and 49-54 perforated scales in the lateral series in $A$. erythropterus.

Among all the Astyanax species, A. erythropterus is most similar to $A$. pelegrini Eigenmann, 1907 (data taken from Mirande et al., 2006) in having small scales on body, same number of scales around peduncle and total number of analfin rays (18-20 and 41-47, respectively), similar number of perforated scales on the lateral line (49-54 and 46-52 in $A$. pelegrini), and a narrow line of chromatophores in the dorsal midline. However, A. erythropterus has more longitudinal scale rows below the lateral line (8-10 vs.7-8 in A. pelegrini), lower gill-rakers on the first branchial arch (24 vs. about 28 in $A$. pelegrini) a larger distance between the pectoral and pelvicfin origins (18.0-23.1\% vs. 15.8-18.7\% SL in A. pelegrini), and the origin of the anal-fin posterior to a vertical through the base of last dorsal-fin ray ( $v s$. vertical below the last third of the dorsal fin in A. pelegrini).

Comparative material. Argentina: Astyanax abramis: MLP 9427, 2, 102.0-113.0 mm SL, Misiones, río Paraná. Astyanax asuncionensis: MLP 8660, 5, 43.6-61.4 mm SL, Santiago del Estero, 
Bañado de Añatuya. Astyanax chico: MACN-ict 8673, holotype, $69.0 \mathrm{~mm}$ SL, Jujuy, río San Francisco basin, río de Zora in rute 34. Astyanax correntinus: AI 206, 1 c\&s, $71.3 \mathrm{~mm} \mathrm{SL}$, Corrientes, río Paraná in Yahapé City. Astyanax eigenmanniorum: MLP 9160, 6, 36.8-80.2 mm SL, Buenos Aires, Los Talas. Astyanax leonidas: MLP 9580, holotype, $45.6 \mathrm{~mm}$ SL, Misiones, río Paraná basin, headwaters of arroyo Urugua-í. Astyanax ojiara: MLP 9470, holotype, $50.5 \mathrm{~mm} \mathrm{SL}$, Misiones, arroyo Benítez, headwaters of arroyo Yabotí-Miní, tributary of río Uruguay. Astyanax paris: MLP 9584, holotype, $75.6 \mathrm{~mm} \mathrm{SL}$, Misiones, río Uruguay basin, arroyo Fortaleza. Astyanax pynandi: MACN-ict 8543, holotype, $52.0 \mathrm{~mm}$ SL, Corrientes, Esteros del Iberá, laguna Iberá, Lobo-Cua. Astyanax rutilus: MLP 8668, 4, 61.0-67.7 mm SL, Santiago del Estero, Bañado de Figueroa. Astyanax saguazu: MLP 9603, holotype, $63.0 \mathrm{~mm}$ SL, Misiones, río Uruguay basin, arroyo Once Vueltas. Astyanax stenohalinus: AI132, 2 c\&s, 42.6-55.7 mm SL, Buenos Aires, Punta Indio, unnamed stream, Río de la Plata basin. Astyanax troya: MACN 8310, holotype, $73.8 \mathrm{~mm}$ SL, Misiones, arroyo Cuñapirú Chico, río Paraná basin. Astyanax tupi: MACN-Ict 8646, holotype, 70.1 $\mathrm{mm}$ SL, Misiones, arroyo Cuñapirú Chico. Paraguay: Ctenobrycon alleni: CAS 57616 (IU10158), holotype, $80.0 \mathrm{~mm} \mathrm{SL}$, Asunción, Corumba, río Otuquis.

\section{Acknowledgements}

We thank Ariel Paracampo (ILPLA) for donating part of the specimens of $A$. erythropterus. Esteban Soibelzon (MLP) helped in the elaboration of the map. Support for field trip was provided by the Comisión de Investigaciones de la Provincia de Buenos Aires (CIC) to JRC, Agencia Nacional de Promoción Científica, and Administración de Parques Nacionales (APN).

\section{Literature Cited}

Almirón, A. E., M. Azpelicueta \& J. R. Casciotta. 2002. Astyanax ita sp. n. - a new species from the Río Iguazú basin, in Argentina (Teleostei, Characiformes, Characidae). Zoologische Abhandlungen, Staatliche Naturhistorische Sammlungen Dresden, Museum für Tierkunde, 52: 3-10.

Azpelicueta, M., A. E. Almirón \& J. R. Casciotta. 2002. Astyanax paris: A new species from the Río Uruguay basin of Argentina (Characiformes, Characidae). Copeia, 2002(4): 1052-1056.

Azpelicueta, M., J. M. Mirande, A. E. Almirón \& J. R. Casciotta. 2003. A new species of Astyanax (Characiformes, Characidae) from Paraná river basin in Argentina. Revista del Museo de La Plata, 15(166): 1-12.

Bertaco, V. A. \& C. A. S. Lucena. 2006. Two new species of Astyanax (Ostariophysi: Characiformes: Characidae) from eastern Brazil with a synopsis of Astyanax scabripinnis species complex. Neotropical Ichthyology, 4(1): 53-60.

Casciotta, J. R., A. E. Almirón, \& M. Azpelicueta. 2003. A new species of Astyanax from río Uruguay basin, Argentina (Characiformes: Characidae). Ichthyological Exploration of Freshwaters, 14(4): 329-334.

Cordiviola de Yuan, E., N. Oldani, O. Oliveros \& C. Pignalberi de Hassan. 1984. Aspectos limnológicos de ambientes próximos a la ciudad de Santa Fé (Paraná Medio): Poblaciones de peces ligados a la vegetación. Neotrópica, 30(84): 127-139.

Eigenmann, C. H. 1910. Catalogue of the fresh-water fishes of tropical and south temperate America. Reports of the Princeton University Expeditions to Patagonia, Zoology, 3(2): 375-511.
Ferraris, C. J., Jr. 2007. Checklist of catfishes, recent and fossil (Osteichthyes: Siluriformes), and catalogue of siluriform primary types. Zootaxa, 1418: 1-300.

Fink, W. L. \& S. H. Weitzman. 1974. The so-called cheirodontin fishes of Central America with descriptions of two new species (Pisces: Characidae). Smithsonian Contributions to Zoology, 172: 1-146.

Géry, J. 1977. Characoids of the World. New Jersey. T. F. H. Publications, Neptune City, 672p.

Holmberg, E. L. 1891. Sobre algunos peces nuevos o poco conocidos de la República Argentina. Revista Argentina de Historia Natural, Buenos Aires, 1: 180-193.

Liotta, J. 2006. Distribución geográfica de los peces de aguas continentales de la República Argentina. ProBiota, Serie Documentos, 3: 1-701.

Liotta, J., B. Giacosa \& M. Wagner. 1995, 1996. Lista comentada de la ictiofauna del delta del río Paraná. Revista de Ictiología, 4(1-2): 23-32.

López, H. L., A. M. Miquelarena \& R. C. Menni. 2003. Lista comentada de los peces continentales de la Argentina. ProBiota, Serie Técnica y Didáctica 5: 1-85.

Menni, R. C. 2004. Peces y ambientes en la Argentina continental. Monografías del Museo Argentina Ciencias Naturales, Buenos Aires, 5: 1-316.

Mirande, J. M., G. Aguilera \& M. Azpelicueta. 2004. A new species of Astyanax (Characiformes, Characidae) from the upper río Bermejo basin, Salta, Argentina. Revue suisse de Zoologie, 111(1): 213-223.

Mirande, J. M., M. Azpelicueta \& G. Aguilera. 2006. Redescription of Astyanax correntinus (Holmberg, 1891) (Teleostei: Characiformes: Characidae), more than one hundred years after original description. -Zoologische Abhandlungen, Staatliche Naturhistorische Sammlungen Dresden, Museum für Tierkunde, 55: 9-15.

Pozzi, A. J. 1945. Sistemática y distribución de los peces de agua dulce de la República Argentina. Gaea, 7: 239-292.

Ringuelet, R. A., R. H. Arámburu \& A. Alonso de Arámburu. 1967. Los peces de agua dulce de la República Argentina. Comisión de investigaciones Científicas de la Provincia de Buenos Aires, 602p.

Taylor, W. R. \& G. C. van Dyke. 1985. Revised procedures for staining and clearing small fishes and other vertebrates for bone and cartilage study. Cybium, 9(2): 107-119.

Accepted August 13, 2010 Published December 16, 2010 